\title{
The Influence of Proflavine on the Synthesis of Foot-and-Mouth Disease Virus
}

\author{
BY F. BROWN AND DOREEN L. STEWART \\ Research Institute (Animal Virus Diseases), Pirbright, Surrey
}

(Received 5 May 1960)

\begin{abstract}
SUMMARY
Infective ribonucleic acid (RNA) can be extracted with phenol from virusinfected pig kidney tissue-culture cells before the appearance of new complete virus. In the early stages of multiplication, however, infective RNA cannot be obtained from the cells if they are incubated with ribonuclease before treatment with phenol. This suggests that the infective RNA is in a 'free' enzyme-sensitive form at this time. At the end of the lag phase, as the RNA is incorporated into complete virus, there is a decrease in the proportion of infective RNA in the cells which is sensitive to the enzyme. Nine hours after infection all the material in the cells which yields infective RNA on treatment with phenol is insensitive to ribonuclease. Incorporation of low concentrations of proflavine into the incubation medium decreases considerably the yield of infective virus, although the amounts of infective RNA and specific complement-fixing antigen are not proportionately reduced. In the presence of proflavine the RNA in the cells remains sensitive to ribonuclease throughout the growth cycle indicating that the compound prevents the incorporation of RNA into complete virus. The complement-fixing antigen produced in the proflavine inhibited system is the $7 \mathrm{~m} \mu$ non-infective component of the virus.
\end{abstract}

\section{INTRODUCTION}

It has recently been shown (Brown \& Stewart, 1959 $a$ ) that infective RNA can be obtained from pig kidney-tissue culture cells infected with foot-and-mouth (FMD) virus before new infective virus is formed. In the present paper it is shown that the infective RNA which can be detected in the cells in the lag phase is completely destroyed by ribonuclease. As the RNA becomes incorporated into virus there is a decrease in the proportion of infective RNA in the cells which is sensitive to the enzyme. A similar sequence of events occurs during the multiplication of tobacco mosaic virus in tobacco leaves (Engler \& Schramm, 1959), and Sanders (1960) has shown that infective RNA is formed during the lag phase following infection of mouse ascites carcinoma cells with mouse encephalomyocarditis virus. This RNA, however, is present in a form which is insensitive to treatment with ribonuclease even before it is incorporated into complete virus.

It is generally considered that proflavine inhibits the formation of infective bacteriophages by blocking in some way the linkage of the phage DNA and protein which are still formed in the presence of the dye. The production of virus specific proteins, without the accompanying formation of fully infective virus, also occurs 
in the presence of proflavine with the viruses of poliomyelitis (Ledinko, 1958) and fowl plague (Franklin, 1958b). We show here that infective RNA and viral protein are still produced in the presence of proflavine in cultures of pig kidney cells infected with FMD virus although the yield of infective virus is considerably reduced. Some preliminary observations on the inhibition of FMD virus synthesis by proflavine have already been published (Brown \& Stewart, 1959b).

\section{METHODS}

Virus and RNA preparations. Virus of strain 997 (Waldmann type C) passaged in pig kidney monolayers and harvested at $18 \mathrm{hr}$. was used for infecting the cell monolayers and suspensions. Infective RNA was prepared from the infected cells by the cold phenol method of Gierer \& Schramm (1956) modified to cover the requirements of the acid-sensitive FMD virus (Brown \& Stewart, 1959a). All the manipulations were carried out at $0-4^{\circ}$ and the RNA preparations were assayed as quickly as possible after preparation. In all the experiments the maximum time required for phenol extraction and inoculation of the RNA on to pig kidney monolayers was $50 \mathrm{~min}$. Each preparation of RNA was tested to ensure that it was free from residual virus by showing that the infectivity was destroyed by the addition of $1 / 10$ volume of normal bovine serum or $10 \mu \mathrm{g}$. crystalline ribonuclease $/ \mathrm{ml}$.

Titration of virus and $R N A$. Virus was titrated throughout by inoculating $0.03 \mathrm{ml}$. doses of tenfold dilutions intraperitoneally into groups of four or five 7-day mice (Skinner, 1951). For the estimation of the amount of virus in cells or cell suspensions sodium dodecylsulphate was added to a final concentration of $0.1 \%$ to disrupt the cells before dilution. This procedure had no effect on the titre of virus suspensions (Cartwright \& Thorne, 1959). RNA was estimated by observing the cytopathic effects produced by $\mathbf{0 . 2} \mathrm{ml}$. aliquots in pig kidney monolayers (4 or 5 monolayers per tenfold dilution). The $50 \%$ end-points were calculated by the method of Reed \& Muench (1938) and the virus or RNA content expressed in ID 50/ml.

Titration of complement-fixing antigen. Brooksby's (1952) method was used. Comparison of the amounts of complement-fixing antigens present in suspensions in any individual experiment was made by determining the dilution of each suspension which fixed the same amount of complement. The harvested cells were ground in a mortar in the supernatant fluid and the debris then removed by centrifugation. Concentration of the fluids was achieved by dialysis against polyethylene glycol (Kohn, 1959).

Infection of pig kidney cell cultures. Primary cultures of pig kidney cells were suspended in Hanks' saline containing $0.5 \%$ lactalbumin hydrolysate and $0.01 \%$ yeast extract. Suspensions containing $2-4 \times 10^{6}$ cells $/ \mathrm{ml}$. were infected to give a multiplicity of infection of 1 . After $30 \mathrm{~min}$. at $37^{\circ}$, the cells were washed three times and resuspended in the same medium so that the final concentration of cells was approximately $2 \times 10^{5} / \mathrm{ml}$. Samples of the suspensions were removed at intervals for estimations of virus and infective RNA.

Detection of 'free' $R N A$ in infected cells. Samples of the infected cell suspensions were centrifuged, the supernatant removed and the cells resuspended in modified Hanks's saline. The suspensions were then divided into two portions. One was cooled to $0^{\circ}$ and then extracted with phenol; the other was ground in a mortar after 
the addition of ribonuclease $\left(20 \mu \mathrm{g} . / \mathrm{ml}\right.$.), held at $20^{\circ}$ for $15 \mathrm{~min}$., then cooled to $0^{\circ}$ and extracted with phenol. The first procedure yields total RNA, whereas the second procedure gives RNA which is resistant to ribonuclease when it is present in the cells. The difference between the two estimations was taken as 'free RNA', although it is not known whether the RNA is really free or bound to some other material.

Proflavine experiments. Because of the photodynamic action of proflavine on the virus (Galloway, 1937) subdued light was used in all the experiments involving the use of this compound.

\section{RESULTS}

\section{Relationship between virus and $R N A$ titres}

The accuracy of the titration methods and the reproducibility of the phenol method for extracting infective RNA from the cells were determined experimentally. Four aliquots of virus-infected pig kidney cells, taken after $7 \mathrm{hr}$. incubation at $37^{\circ}$, were cooled to $0^{\circ}$ and extracted with phenol. Each was then titrated in pig kidneycell monolayers. One of the RNA preparations was also titrated four times. The virus content of the cells was estimated by four separate titrations in mice after first disrupting the cells with sodium dodecylsulphate. Values of $10^{7.0}, 10^{6.8}, 10^{6.8}$, and $10^{6.5} \mathrm{ID} \mathrm{50} / \mathrm{ml}$. were obtained for the virus titrations and $10^{2 \cdot 2}, 10^{2.0}, 10^{2.0}$ and $10^{1.7} \mathrm{ID} \mathrm{50} / \mathrm{ml}$. for the RNA titration. In addition, the preparation of RNA which was titrated four times gave values of $10^{2 \cdot 2}, 10^{2 \cdot 0}, 10^{2 \cdot 0}$ and $10^{1 \cdot 7} \mathrm{ID} \mathrm{50} / \mathrm{ml}$.

In this and other unpublished work it has been found that standard virus preparations containing $10^{7.0} \mathrm{ID} \mathrm{50} / \mathrm{ml}$. yield about $10^{2.0} \mathrm{ID} \mathrm{50} / \mathrm{ml}$. infective RNA on treatment with phenol. Similarly $10^{6.0} \mathrm{ID} \mathrm{50} / \mathrm{ml}$. of virus give about $10^{1.0} \mathrm{ID} \mathrm{50} / \mathrm{ml}$. of RNA. With virus suspensions containing $10^{5.0} \mathrm{ID} \mathrm{50} / \mathrm{ml}$. however, infective RNA has generally been detected infrequently in the phenol extracts and then only in one out of four or five monolayers inoculated with the undiluted extract. In the lag phase of the growth cycle, however, when the major contribution to the infective RNA content of the phenol extract is made by viral precursors, infective RNA can be detected in extracts of cells which have much lower infectivity titres (see Fig. 1 $a$ ).

\section{Growth of the virus and its infective $R N A$}

There is an initial lag phase of about $1.5 \mathrm{hr}$. (measured from the end of the adsorption period) before the infectivity titre of the suspension starts to increase. Treatment of the infected cells with phenol during the lag phase yielded infective RNA, usually about $0 \cdot 25-0.5 \mathrm{hr}$. before the virus titre started to rise (Fig. 1a). All the infective RNA present in the cells at this stage was rendered non-infective by treatment of the ground cells with ribonuclease (Fig. 1b). With the appearance of complete virus in the cells, however, there was a decrease in the proportion of 'free' RNA. During the $4 \mathrm{hr}$. period when the virus titre was increasing most rapidly about $80-90 \%$ of the RNA was in the 'free' state. As the rate of virus synthesis decreased, the percentage of 'free' RNA declined rapidly and after $9 \mathrm{hr}$. all the infective RNA in the cells was resistant to ribonuclease. Virus synthesis had finished by this time (Fig. 1 $a$ ). The complement-fixing titre of the suspension reached its maximum at about the same time, affording further evidence for this conclusion. 
Control experiments showed that the action of the added ribonuclease was stopped immediately on addition of the incubated mixture of ground cells and enzyme to the cold phenol. Consequently the lower yield of infective RNA, obtained after treatment of the cells with ribonuclease, cannot be accounted for by enzymic destruction of the RNA after release by phenol treatment.

In contrast to the results obtained with the cells, treatment of the supernatant with ribonuclease during the early stages of virus growth did not lead to a diminution in the yield of infective RNA. It appears, therefore, that the cells do not discharge 'free' RNA into the medium along with complete virus unless any 'free' RNA released by the cells is destroyed rapidly in the medium.
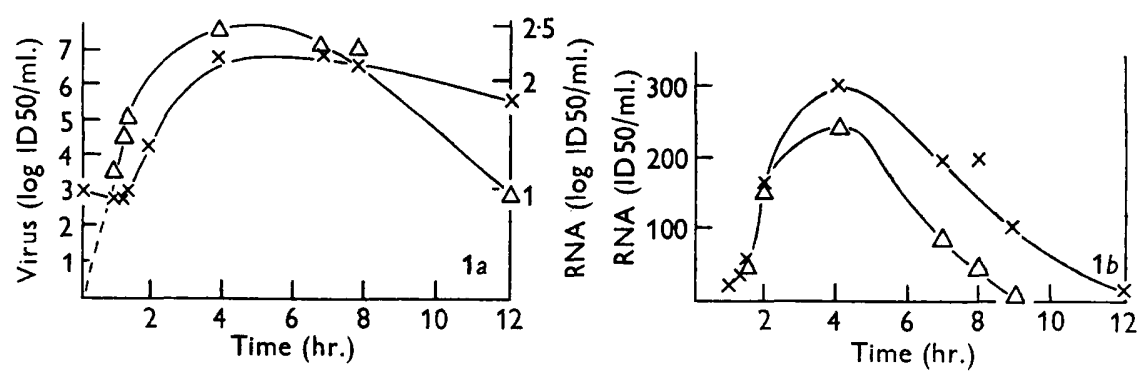

Fig. 1. (a) Intracellular production of infective virus $(x-x)$ and infective RNA $(\triangle-\triangle)$ in pig kidney cells infected with FMD virus. (b) Relative amounts of total infective RNA $(x-x)$ and ribonuclease sensitive RNA $(\Delta-\Delta)$ in the cells during the growth cycle.

\section{Effect of proflavine on virus and RNA synthesis in pig kidney cells}

The marked inhibition of virus growth which occurs on incubating FMD virusinfected cell monolayers in medium containing proflavine was described in a preliminary report (Brown \& Stewart, 1959b). When suspensions of cells were used instead of monolayers, a similar though less-marked inhibition of virus production was observed. For example, at a concentration of $1.5 \mu \mathrm{g}$. proflavine $/ \mathrm{ml}$. the yield of virus at $4 \mathrm{hr}$. was $2 \cdot 0-2 \cdot 5$ logs lower than in control cultures in monolayers while in suspensions the inhibition was $1 \cdot 5-2 \cdot 0$ logs. This difference is probably related to the different concentrations of cells in the two systems as the inhibition of virus production in the presence of $1.5 \mu \mathrm{g}$. proflavine $/ \mathrm{ml}$. can be eliminated by increasing the concentration of cells to $2 \times 10^{6} / \mathrm{ml}$.

Figure 2 shows typical results with virus-infected cell suspensions containing 0-2 $\mu \mathrm{g}$. proflavine/ml. Most of the experiments have been made in this range of concentration as the yield of virus was reduced by a factor of 10 or more without a proportionate reduction in the yield of infective RNA and viral protein. In forty experiments the ratio $\log _{10}$ virus: $\log _{10}$ RNA with suspensions harvested at $4 \mathrm{hr}$. was 3 or less in suspensions containing $1 \cdot 5-2 \cdot 0 \mu \mathrm{g}$. proflavine $/ \mathrm{ml}$., whereas the ratio in control cultures without proflavine was 4 to 5 . Figure 2 also shows that the infective RNA was produced as early in the growth cycle in the pressure of $1.5 \mu \mathrm{g}$. proflavine $/ \mathrm{ml}$. as in uninhibited cultures.

About $50 \%$ of the infective RNA which could be obtained from control infected cells at $7 \mathrm{hr}$. was in a form resistant to the action of ribonuclease (Table 1 and 
Fig. 1b). However, we were unable to detect any infective RNA in the phenol extracts prepared from virus-infected cells which had been incubated in the presence of $1.5 \mu \mathrm{g}$. proflavine $/ \mathrm{ml}$, if these cells were first ground with ribonuclease before extraction. The amount of ribonuclease-resistant RNA in the proflavine inhibited cells must therefore be less than $1 \%$ of the total infective RNA. The amount of virus present in the proflavine-inhibited culture at this time (10.0 ID 50/ ml.) is just enough to yield detectable infective RNA with the techniques used in this work.
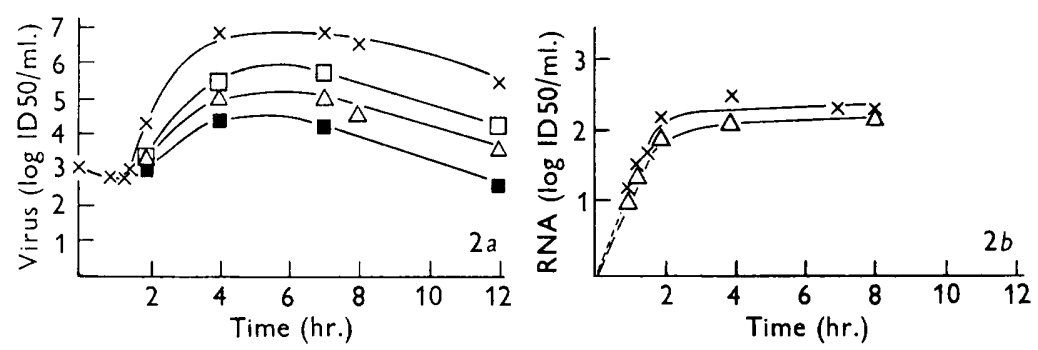

Fig. 2. (a) Production of virus in pig kidney cells following infection with FMD virus and incubation in the presence of proflavine: Control $(x-x) ; 1.0 \mu \mathrm{g} . / \mathrm{ml} .(\square-\square)$; $1.5 \mu \mathrm{g} . / \mathrm{ml} .(\triangle-\triangle) ; 2.0 \mu \mathrm{g} . / \mathrm{ml}$. ( $\square-\square)$. (b) Effect of proflavine on the production of infective RNA by pig kidney cells infected with FMD virus : Control $(x-x) ; 1 \cdot 5 \mu \mathrm{g} . / \mathrm{ml}$. $(\Delta-\Delta)$.

Table 1. Effect of proflavine on the production of virus and infective RNA by FMD-virus infected pig kidney cells

\begin{tabular}{|c|c|c|c|c|c|c|}
\hline \multirow[b]{2}{*}{ Medium } & \multicolumn{2}{|c|}{$\begin{array}{c}\text { Virus titre } \\
(\log \text { ID 50/ml.) }\end{array}$} & \multicolumn{2}{|c|}{$\begin{array}{c}\text { RNA titre } \\
(\log \text { ID 50/ml. })\end{array}$} & \multicolumn{2}{|c|}{$\begin{array}{c}\text { RNAse-resistant } \\
\text { RNA titre } \\
(\log \text { ID 50/ml.) }\end{array}$} \\
\hline & $4 \mathrm{hr}$. & f hr. & $4 \mathrm{hr}$. & $7 \mathrm{hr}$. & $4 \mathrm{hr}$. & $7 \mathrm{hr}$. \\
\hline Control & $6 \cdot 8$ & $6 \cdot 8$ & $\mathbf{2 \cdot 5}$ & $2 \cdot 3$ & $1 \cdot 7$ & $2 \cdot 0$ \\
\hline 1.5 $\mu \mathrm{g}$. proflavine $/ \mathrm{ml}$. & $\mathbf{5} \cdot 0$ & $5 \cdot 0$ & $\mathbf{2 \cdot 2}$ & $2 \cdot 2$ & Nil & Nil \\
\hline
\end{tabular}

\section{Effect of proflavine on protein synthesis}

In the preliminary work with monolayers, virus specific complement-fixing antigens could not be detected in the $24 \mathrm{hr}$. harvests from the infected cell monolayers incubated in the presence of $2 \mu \mathrm{g}$. proflavine $/ \mathrm{ml}$., even after five-fold concentration of the material. With virus-infected suspensions incubated in the same concentration of proflavine only a trace of complement-fixing antigen was detected. In no case was there more than $5 \%$ of the activity of the control culture. In the presence of $1.5 \mu \mathrm{g}$ proflavine $/ \mathrm{ml}$., however, about $50 \%$ of the normal yield of complement-fixing antigen was formed. It was possible to compare the yields of complement-fixing antigens only after 4 or more hours incubation. Before that time the amount present, even after concentrating the control cultures, was usually insufficient to determine with accuracy. Table 2 shows the relative amounts of complement fixed at several time intervals during the multiplication cycle. Compared with the control, the amount of antigen formed in the presence of a fixed concentration of proflavine did not alter significantly during the growth cycle. 
Identity of complement-fixing antigen in proflavine inhibited cultures

Suspensions of FMD virus prepared from infected animal tissues or tissue cultures contain two complement-fixing antigens: the infective $20 \mathrm{~m} \mu$ component and a $7 \mathrm{~m} \mu$ non-infective component. The effect of proflavine on the synthesis of these two components was studied in two ways:

Table 2. Effect of proflavine on the complement-fixing activity of virus infected cell suspensions at different stages of multiplication

$\begin{array}{ccccr}\begin{array}{c}\text { Proflavine } \\ (\mu \mathrm{g} . / \mathrm{ml} .)\end{array} & 4 \mathrm{hr} . & 6 \mathrm{hr} . & 7.5 \mathrm{hr} . & 24 \mathrm{hr} . \\ 0 & 0.07 & 0.16 & 0.20 & 0.28 \\ 1.0 & - & - & 0.10 & 0.14 \\ 1.5 & 0.04 & 0.08 & 0.09 & 0.12 \\ 2.0 & - & - & 0.01 & 0.01\end{array}$

(a) Agar gel diffusion. This is a simple qualitative method for determining the antigens present in FMD virus suspensions (Brown \& Crick, 1958). It was first necessary to concentrate the harvested tissue culture fluids about 100-fold by dialysis against polyethylene glycol (Kohn, 1959). The volumes of the concentrates were adjusted so that they had the same complement-fixing titre, and then diffused from adjacent cups towards a cup containing the homotypic hyperimmune guineapig serum. The control virus suspension ( $A$ and $\mathbf{D})$ produced two precipitin bands, whereas the suspension containing $1.5 \mu \mathrm{g}$, proflavine $/ \mathrm{ml}$. (B) produced one band identical with that formed by the $7 \mathrm{~m} \mu$ component of the control (C and $\mathrm{E})$, together

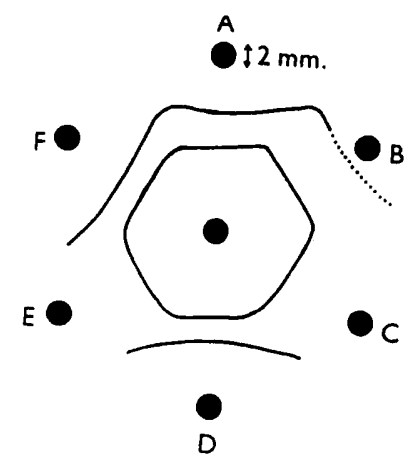

Fig. 3. Diagrammatic representation of the agar precipitin pattern obtained with virus antigens produced by pig kidney cells in the presence of proflavine: $A$ and $D$-standard virus preparation; $B$-virus antigens obtained in the presence of $1.5 \mu \mathrm{g}$. proflavine $/ \mathrm{ml}$.; $\mathrm{C}$ and $\mathrm{E}-7 \mathrm{~m} \mu$ component separated from virus $; \mathrm{F}$ - standard virus preparation incubated with $2 \mu \mathrm{g}$. proflavine/ml.

with a very faint $20 \mathrm{~m} \mu$ component band (Fig. 3). To determine whether proflavine had any effect on the precipitin band pattern produced by normal virus suspensions, $2 \mu \mathrm{g} . / \mathrm{ml}$. of the dye was added to the control virus suspension and allowed to stand on the laboratory bench for $3 \mathrm{hr}$. The virus suspension treated in this way $(F)$ gave a precipitin pattern identical with that of the untreated concentrate although it was then non-infective for mice.

(b) Effect on neutralizing activity of antiserum. The fluids harvested from cell sus- 
pensions incubated for $24 \mathrm{hr}$. in normal medium or medium containing $1.5 \mu \mathrm{g}$. proflavine $/ \mathrm{ml}$. were rendered non-infective by treatment with acetylethyleneimine (Brown \& Crick, 1959). This compound inactivates FMD virus without altering its serological structure as determined by agar diffusion. The inactivated suspensions were dialysed free from the imine and incubated with $1 / 1000$ hyperimmune guineapig serum at $37^{\circ}$ for $3 \mathrm{hr}$. Aliquots of the mixtures were then incubated with dilutions of virus at $37^{\circ}$ for $1 \mathrm{hr}$. and titrated in mice. The reduction of the neutralizing activity of the serum by the inactivated suspensions was in direct relation to the initial virus content of the suspensions (Table 3). Whereas 1/1000 serum lowered the titre of the test virus from $10^{6.8}$ to $10^{3 \cdot 3} \mathrm{ID} \mathrm{50} / \mathrm{ml}$. (i.e. a neutralizing titre of $10^{3.5}$ ) a mixture of the same dilution of serum and the inactivated control virus suspension did not lower the titre of the test virus, showing that all the neutralizing activity of the serum had been blocked by the inactivated virus suspension. In contrast the proflavine inhibited suspension, although containing half as much complement fixing antigen as the control suspension, lowered the neutralizing titre of the serum by only $10^{1 \cdot 7}$. This result indicates the absence from the proflavine inhibited suspensions of a non-infective antigen capable of reducing the virus neutralizing antibody titre of homotypic antiserum. The $7 \mathrm{~m} \mu$ component of the virus separated from the control virus suspension by ultracentrifugation and subsequently treated with acetylethyleneimine to remove traces of residual infective virus, had only a slight effect on the neutralizing antibody titre of the serum (Table 3).

\section{Influence of proflavine on the cytopathic effects produced in pig kidney cells by foot-and-mouth disease virus}

When pig kidney monolayers were infected with virus and treated immediately with proflavine, cytopathic changes occurred similar to those observed in untreated, infected cells. In order to examine these changes in the two systems, pig kidney cells were grown as monolayers on coverslips, infected with virus and incubated in growth medium with or without proflavine. Coverslips were removed at intervals after infection and the cells fixed and stained with Giemsa or haematoxylin. During the lag period no changes in the stained appearance of the cells could be detected in either system, but after $2 \mathrm{hr}$. cells in the absence of proflavine showed marked cytopathic changes with increased nuclear pyknosis and shrinkage of the cytoplasm. Similar changes occurred in the presence of proflavine, but these were detected only after about $4 \mathrm{hr}$. incubation. In both cases, however, $24 \mathrm{hr}$. incubation resulted in almost complete degeneration of all the cells, accompanied by an increase in virus titre only in cells free from proflavine. (Cytopathic changes in infected cells incubated with proflavine occurred without similar increase in virus titre.)

This lack of correlation between cellular injury and virus increase has also been seen with HeLa cells infected with poliovirus and subsequently incubated in the presence of proflavine (Ledinko, 1958) or $p$-fluorophenylalanine (Ackermann, Rabson \& Kurtz, 1954).

\section{Effect of proflavine on infectivity of virus suspensions in the presence of light}

As Galloway (1937) has shown that proflavine has a photodynamic action on suspensions of FMD virus, it was necessary to use subdued lighting conditions. This 
aspect of the action of proflavine on viruses appears to have been overlooked recently despite the evidence put forward nearly 30 years ago that the dye had a photodynamic action on several phages and viruses (Burnet, 1933). The recent work of Kaufman \& Hiatt (1959) with $\boldsymbol{T}_{2}$ coliphage emphasizes this point.

The subdued lighting used in the present work was controlled as follows. Virus suspensions were held at room temperature for $2 \mathrm{hr}$. with or without the addition of $2 \mu \mathrm{g}$. proflavine/ml., in daylight or in subdued light. The suspensions were then

Table 3. Effect of addition of viral antigens on the virus neutralizing titre of hyperimmune guinea-pig antiserum

\begin{tabular}{|c|c|c|c|}
\hline Antigen & $\begin{array}{c}\text { Virus titre of } \\
\text { antigen* } \\
(\log 1050 / \mathrm{ml} .)\end{array}$ & $\begin{array}{c}\text { Virus titre of } \\
\text { mixture } \dagger \\
\text { (log ID 50/ml.) }\end{array}$ & $\begin{array}{c}\text { Diminution of } \\
\text { neutralizing } \\
\text { activity } \\
\text { of serum } \\
(\log \text { ID 50) }\end{array}$ \\
\hline Control virus & $7 \cdot 0$ & $6 \cdot 8$ & $\mathbf{3 \cdot 5}$ \\
\hline Control at $1 / 10$ & $6 \cdot 0$ & $6 \cdot 0$ & $2 \cdot 7$ \\
\hline $\begin{array}{l}\text { Antigen produced in presence of } 1.5 \mu \mathrm{g} \\
\text { proflavine } / \mathrm{ml} \text {. }\end{array}$ & $5 \cdot 2$ & $\mathbf{5 \cdot 0}$ & $1 \cdot 7$ \\
\hline $7 \mathrm{~m} \mu$ component & $\mathbf{2 \cdot 0}$ & $3 \cdot 5$ & $0 \cdot 2$ \\
\hline Buffer control & - & $\mathbf{3 \cdot 3}$ & - \\
\hline
\end{tabular}

Test virus diluted with an equal vol. phosphate buffer contained $10^{6 \cdot 8} \mathrm{ID} \mathrm{50} / \mathrm{ml}$. This titre was reduced to $10^{3^{* 3}} \mathrm{ID} \mathrm{50} / \mathrm{ml}$. by $1 / 1000$ serum, i.e. neutralization titre of serum $=10^{3^{\circ} 5}$.

* All antigens were inactivated with acetylethyleneimine before use in the test. The titre shown was the maximum achieved during the growth cycle.

$\dagger$ Mixture $=($ inactivated antigen $+1 / 1000$ antiserum $)+$ virus dilutions.

compared for virus infectivity and also for the yield of infective RNA on treatment with phenol. The destruction of virus infectivity in the presence of proflavine was accompanied by the loss of infective RNA (Table 4). This also shows that the reduction of virus yield in infected cells in the presence of proflavine without the proportionate reduction in RNA titre is not due to a differential photodynamic effect. In the lighting conditions used in the experiments, no loss of virus or RNA infectivity was encountered.

Table 4. Effect of proflavine on the titre of virus suspensions

\begin{tabular}{lcc}
\multicolumn{1}{c}{ Treatment } & $\begin{array}{c}\text { Virus titre } \\
(\log \text { ID 50/ml.) }\end{array}$ & $\begin{array}{c}\text { Titre of RNA } \\
(\log \text { ID 50/ml.) }\end{array}$ \\
None & $5 \cdot 8$ & $1 \cdot 2$ \\
$2 \mu \mathrm{g}$. proflavine in daylight & Non-infective & None-infective \\
$2 \mu \mathrm{g}$. proflavine in subdued light & $5 \cdot 8$ & $1 \cdot 3$
\end{tabular}

\section{DISCUSSION}

It is generally considered, by analogy with the results obtained with bacteriophage, that animal and plant viruses break down into smaller units as they penetrate the susceptible host cell. Apart from the results of Hoyle and his colleagues (e.g. Hoyle \& Frisch-Niggemeyer, 1955; Hoyle \& Finter, 1957) with influenza virus and the recent findings of Sanders (1960) with mouse encephalomyocarditis virus, however, there is little direct experimental evidence to support this view, although the recent findings that RNA, isolated from a number of different animal viruses, can initiate in a suitable host an infection indistinguishable from that produced by the parent 
virus has rendered the hypothesis more attractive. We provide further evidence in favour of the hypothesis in the case of FMD virus and also confirm that the employment of biochemical inhibitors may be useful in elucidating the mechanism of virus synthesis. The demonstration of infective RNA in pig kidney cells infected with foot-and-mouth disease virus before the appearance of new virus suggested that the RNA and viral protein were formed separately in the cell before they combined to yield complete virus. This suggestion was strengthened in the case of the RNA by the observation that ribonuclease treatment of the cells at this stage of virus. synthesis destroyed the RNA, indicating that it was in a free, enzyme-sensitive form. As the RNA became incorporated into virus this sensitivity to ribonuclease decreased. The virus itself was not affected by the enzyme. This is similar to the finding of Engler \& Schramm (1959) with tobacco mosaic virus. The results of Sanders (1960) with mouse encephalomyocarditis virus suggest that the multiplication of this virus is different from that of tobacco mosaic or FMD, as the infective RNA in this case is in a form which is insusceptible to ribonuclease even before it is incorporated into complete virus.

Proflavine inhibits the growth of bacterial viruses by blocking some process or processes in the latter half of the lag phase concerned with the synthesis of the fully infective virus particle (De Mars, Luria, Fisher \& Levinthal, 1953; de Mars, 1955; Kellenberger \& Séchaud, 1957; Kay, 1959). As proflavine is regarded as inhibiting cytoplasmic protein synthesis, the possibility of a differential block on the synthesis of virus subunits was investigated, following the interesting results obtained by Franklin (1958b) with fowl plague virus and Ledinko (1958) with poliovirus. Franklin showed that S-antigen production in chick embryo tissue culture cells. was not affected by concentrations of proflavine which inhibited the production of infectious particles and haemagglutinin. These observations fitted in well with the observations of Breitenfeld \& Schäfer (1957) and Franklin (1958a) that the S-antigen multiplies in the nucleus and the haemagglutinin in the cytoplasm. Ledinko, on the other hand, showed that the yield of infectious poliovirus was considerably reduced by proflavine although the number of poliovirus-like particles counted by electron microscopy and the complement-fixing activity were the same as the untreated controls.

In the present work with FMD virus, it has been shown that proflavine has a differential effect on the synthesis of infective RNA, virus protein and complete virus. Whereas virus infected cell suspensions incubated in the presence of $1.5 \mu \mathrm{g}$. proflavine/ml. produced between 1 and $10 \%$ of the normal yield of infective virus, the reduction in the yield of infective RNA and viral protein was only about twofold.

The viral protein which is synthesized in the presence of proflavine is the noninfective $7 \mathrm{~m} \mu$ component of the virus and there is no evidence for the production of any other specific antigen. Furthermore, the infective RNA formed in the presence of the dye is not incorporated into a form which is resistant to the action of ribonuclease, as we have failed to obtain any infective RNA from proflavine inhibited cells if these are first treated with ribonuclease before extraction with phenol. It seems, therefore, that whereas in the multiplication of virus in an uninhibited system the $7 \mathrm{~m} \mu$ component and the infective RNA can combine to form the fully infective $20 \mathrm{~m} \mu$ virus particle, in the presence of proflavine the infective RNA and $7 \mathrm{~m} \mu$ component are prevented from combining. 
We wish to thank Dr I. A. Galloway for drawing our attention to the photodynamic action of proflavine on the virus and $\mathrm{Mr}$ B. Cartwright for carrying out the complement-fixation tests.

\section{REFERENCES}

Ackermann, W. W., Rabson, A. \& Kurtz, H. (1954). Growth characteristics of poliomyelitis virus in Hela cell cultures: lack of parallelism in cellular injury and virus increase. J. exp. Med. 100, 437.

Breitenfeld, P. M. \& SchäFer, W. (1957). The formation of fowl plague virus antigen in infected cells, as studied with fluorescent antibodies. Virology, 4, 328.

Brooksby, J. B. (1952). The technique of complement fixation in foot-and-mouth disease research. A.R.C. Rep. Ser. No. 12.

Brown, F. \& Crick, J. (1958). Application of agar-gel precipitin tests to the study of the virus of foot-and-mouth disease. Virology, 5, 133.

Brown, F. \& Crick, J. (1959). Application of agar-gel diffusion analysis to a study of the antigenic structure of inactivated vaccines prepared from the virus of foot-and-mouth disease. J. Immunol. 82, 444.

Brown, F. \& Stewart, D. L. (1959 $a$ ). Studies with infective ribonucleic acid from tissues and cell cultures infected with the virus of foot-and-mouth disease. Virology, 7, 408.

Brown, F. \& Stewart, D. L. (1959b). Effect of proflavine on the formation of the virus of foot-and-mouth disease and its infective ribonucleic acid in pig kidney tissue culture monolayers. Nature, Lond. 184, B.A. 74.

Burnet, F. M. (1933). The classification of dysentery-coli bacteriophages. III. A correlation of the serological classification with certain biochemical tests. J. Path. Bact. 37, 179.

Cartwright, S. F. \& Thorne, H. V. (1959). Some applications of detergents to the study of the virus of foot-and-mouth disease. J. gen. Microbiol. $20,61$.

De Mars, R. I. (1955). The production of phage-related materials when bacteriophage development is interrupted by proflavine. Virology, 1, 83.

De Mars, R. I., Luria, S. E., Fisher, H. \& Levinthal, C. (1953). The production of incomplete bacteriophage particles by the action of proflavine and the properties of the incomplete particles. Ann. Inst. Pasteur, 84, 113.

Engler, R. \& Schramm, G. (1959). Infectious ribonucleic acid as precursor of tobacco mosaic virus. Nature, Lond. $183,1277$.

Frankur, R. M. (1958a). The growth of fowl plague virus in tissue cultures of macrophages and giant cells. Virology, 6,81 .

Frankuin, R. M. $(1958 b)$. The synthesis of fowl plague virus products in a proflavineinhibited tissue culture system. Virology, 6, 525.

Galloway, I. A. (1937). The photodynamic action of dyes on the virus of foot-and-mouth disease. 5th Progr. Rep. Ft Mth Dis. Res. Comm., Appendix III, 342.

Gierer, A. \& Schramm, G. (1956). Infectivity of ribonucleic acid from tobacco mosaic virus. Nature, Lond. 177, 702.

Herzberg, K. (1931). Versuche zur chemischen Beeinflussung des Vakzinevirus. Z Z bl. Bakt. I. Orig. 122, 231.

Hoyle, L. \& Frisch-Niggemeyer, W. (1955). The disintegration of influenza virus particles on entry into the host cell. J. Hyg., Camb. 53, 474.

Hoyle, L. \& FinTER, N. B. (1957). The use of influenza virus labelled with radio-sulphur in studies of the early stages of the interaction of virus with the host cell. J. Hyg., Camb. 55, 290.

Kaufman, E. \& Hiatt, C. W. (1959). Photodynamic action of proflavine on $T_{2}$ coliphage. Virology, 9, 478 .

KAY, D. (1959). The inhibition of bacteriophage multiplication by proflavine and its reversal by certain polyamines. Biochem. $J .73,149$.

Kellenberger, E. \& SÉchaud, J. (1957). Electron microscopical studies of phage multiplication II. Production of phage-related structures during multiplication of phages T2 and T4. Virology, 3, 256 . 
KoнN, J. (1959). A simple method for the concentration of fluids containing protein. Nature, Lond. 183, 1055.

Ledinko, N. (1958). Production of non-infectious complement-fixing poliovirus particles in Hela cells treated with proflavine. Virology, 6, 512.

ReEd, L. T. \& MUENCH, H. (1938). A simple method for estimating 50 per cent end-points. Amer. J. Hyg. 27, 498.

SANDERs, F. K. (1960). Role of nucleic acid in the production of encephalomyocarditis virus. Nature, Lond. 185, 802.

Skinner, H. H. (1951). Propagation of strains of foot-and-mouth disease virus in unweaned white mice. Proc. R. Soc. Med. 44, 1041. 